\title{
Presence of arsenic in Sri Lankan rice
}

\author{
Channa Jayasumana ${ }^{1 *}$, Priyani Paranagama², Saranga Fonseka², Mala Amarasinghe², Sarath Gunatilake ${ }^{3}$ \\ and Sisira Siribaddana ${ }^{4}$
}

\begin{abstract}
Background: Arsenic and heavy metals are implicated in causation of CKDu among farmers in dry zone of Sri Lanka. Rice has been identified as a major source of arsenic in research carried out in other countries. We analyzed 120 samples of new improved varieties (NIVs) and 50 samples of traditional varieties (TV) of rice for total arsenic content.

Findings: Rice cultivated in Sri Lanka is contaminated with arsenic. Agrochemical dependent NIVs contain considerable amount $(20.6-540.4 \mathrm{\mu g} / \mathrm{Kg})$ of arsenic. There is no difference between the arsenic content in NIV rice samples from areas where there is high or low prevalence of CKDu. TVs that are cultivated without using agrochemicals contain significantly less arsenic $(11.6-64.2 \mu \mathrm{g} / \mathrm{Kg})$. However, it is evident that the TVs also contain toxic metals if they are grown with fertilizers and pesticides.

Conclusion: A high proportion of arsenic in rice exists in the inorganic form. Sri Lanka is a nation with high per capita consumption of rice. Codex Alimentarius recommends the maximum allowable limit for inorganic arsenic in rice as $200 \mu \mathrm{g} / \mathrm{kg}$. Assuming that $70 \%$ of the total arsenic content exists in the inorganic form, this corresponds to a level of about $286 \mu \mathrm{g} / \mathrm{kg}$ of total arsenic. As such, 11.6\% of the samples of NIVs exceeded this maximum recommended level in polished rice. Inorganic arsenic is a non-threshold carcinogen. Research should be focused on developing rice varieties that do not retain arsenic within the rice grain.
\end{abstract}

Keywords: Arsenic; Rice; Chronic kidney disease; Sri Lanka; Agrochemicals

\section{Findings}

Arsenic (As) has been a known poison for thousands of years and is classified as a class one non-threshold human carcinogen (Europian Food Safety Authority 2009). Arsenic was not identified as an environmental pollutant in Sri Lanka until recently. Arsenic was identified as a possible etiological factor for the newly emerging epidemic of Chronic Kidney Disease of unknown origin (CKDu), a tubulo-interstitial nephritis among paddy farmers in dry zone of Sri Lanka (Jayasumana et al. 2013; 2014). Analytical studies have shown that a significant amount of arsenic in biological samples (urine, hair and nails) of these CKDu patients (Jayasumana et al. 2013; Jayatilake et al. 2013). Hence, we decided to analyze rice grown in Sri Lanka for arsenic. Analysis was carried out at the department of chemistry, University of Kelaniya and again at the Institute for Integrated Research in Materials, Environments and

\footnotetext{
* Correspondence: jayasumanalk@yahoo.com

${ }^{1}$ Faculty of Medicine\& Allied Sciences, Rajarata University of Sri Lanka,

Saliyapura 50008, Sri Lanka

Full list of author information is available at the end of the article
}

Society (IIRMES) lab, California State University, Long Beach (CSULB), USA.

A total of 170 rice samples were collected from seven different locations to polythene zip bags (Figure 1). There were reported cases of CKDu in and around the sample collection centers from Padaviya, Sripura and Mahawilachchiya but not in at other locations (Kurunegala, Mihinthale, Moneragala and Gampaha). Hundred and twenty of these samples were Newly Improved Varieties (NIV) of rice and were collected directly from paddy farmers. Other 50 samples consisted of 5 different types of traditional varieties (TV) of rice, all cultivated at Kurunegala and Sripura without using agrochemicals but with plant extracts for pest control and with the use of natural fertilizers. Six samples of TVs were purchased from a supermarket in Colombo. They were marketed by a private company and produced, using agrochemicals. Samples were ground using an agate mortar passed through $0.3 \mathrm{~mm}$ sieve before analysis. Atomic absorption spectrometry (AAS) with hydride generation system (GBC 3000) and background corrector (GBC 932 plus GBC

\section{Springer}

(c) 2015 Jayasumana et al.; licensee Springer. This is an Open Access article distributed under the terms of the Creative Commons Attribution License (http://creativecommons.org/licenses/by/4.0), which permits unrestricted use, distribution, and reproduction in any medium, provided the original work is properly credited. 


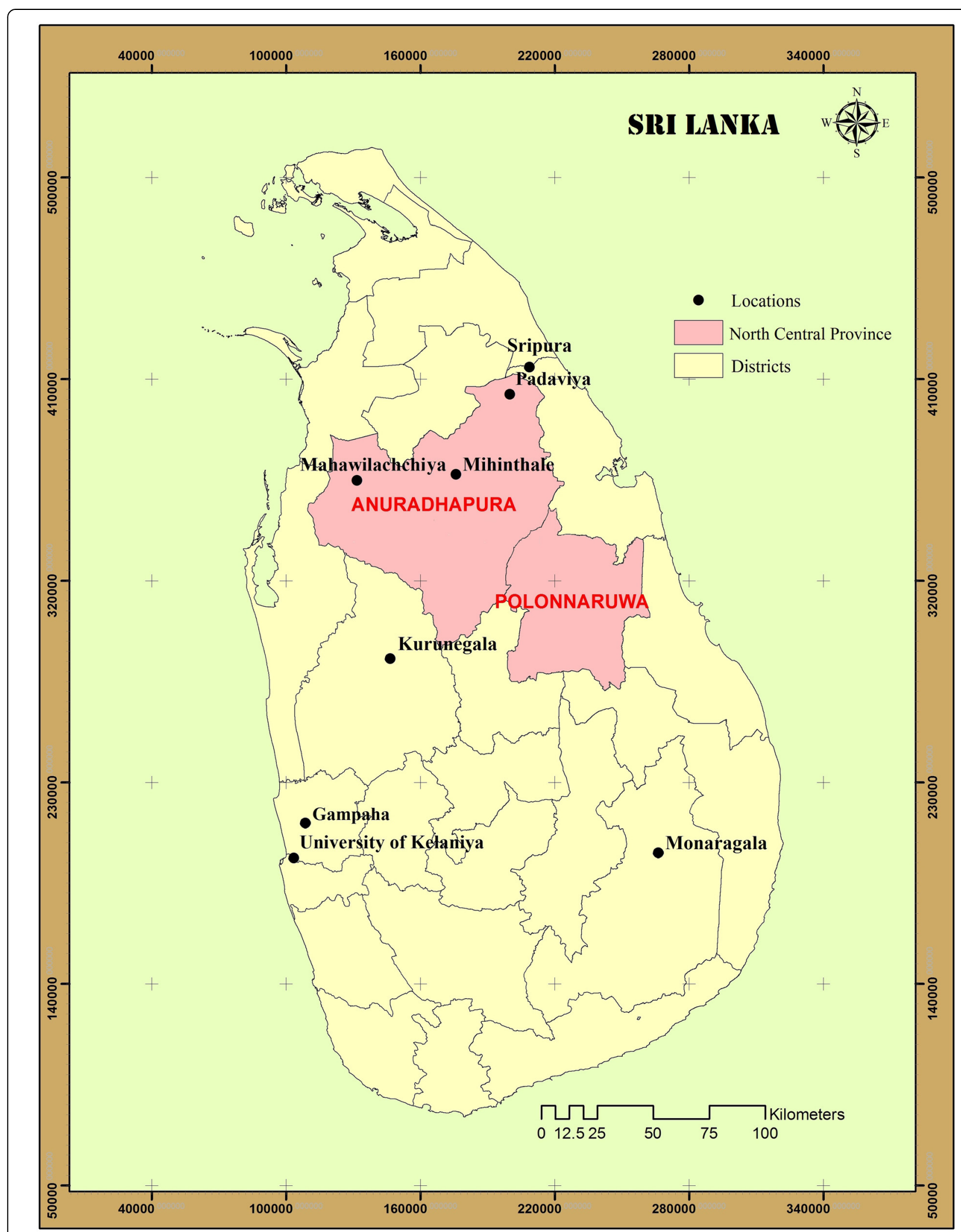

Figure 1 Sample collection sites in a district map of Sri Lanka. 


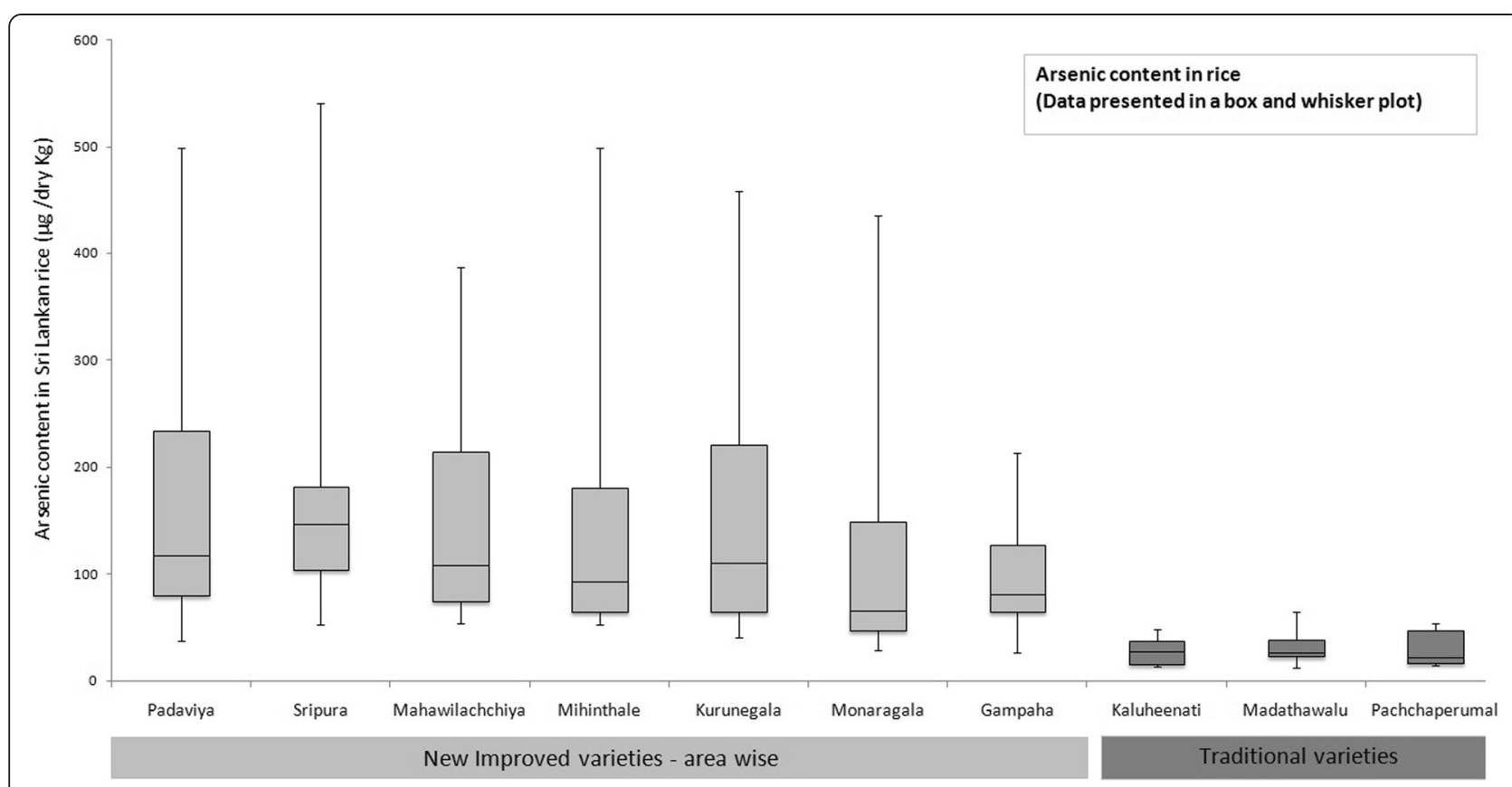

Figure 2 Arsenic content in Sri Lankan rice. Presented as Box and whisker plot ( $\mu \mathrm{g} / \mathrm{dry}$ Kg). *The box represents area between 1 st and 3rd quartile with the center line representing the median. Whiskers represent maximum and the minimum value.

scientific equipment's, VIC, Australia) was used in University of Kelaniya to detect arsenic. Method detection limit (MDL) was $10 \mu \mathrm{g} / \mathrm{Kg}$. Inductively Coupled Plasma Mass Spectrometer (ICP-MS; HP 4500, Agilent Technologies, Palo Alto, CA) equipped with a quadrupole analyzer and octopole collision/reaction cell was used to detect arsenic and other trace metals at IIRMES lab, CSULB (EPA method $6020 \mathrm{~m}$ ). Mercury was detected by cold vapor atomic fluorescence spectroscopy using EPA method 245.7m. MDL was $1 \mu \mathrm{g} / \mathrm{g}$ for aluminum and iron, $0.01 \mu \mathrm{g} / \mathrm{g}$ for mercury and $0.025 \mu \mathrm{g} / \mathrm{g}$ for all other trace metals. Samples tested at IIRMES laboratory are not split samples of those tested in Sri Lanka. Data analysis was done using Microsoft excel 2007.

In 1998, rice has been identified as potentially important source of arsenic to humans for the first time (Yost et al.
1998) and is the largest dietary source of inorganic arsenic (Tsuji et al. 2007). Arsenic accumulation in rice is a newly recognized disaster for South-East Asia (Meharg 2004). Rice is particularly susceptible to arsenic accumulation compared to other cereals because it is grown anaerobically in paddy fields that are flooded (Meharg and Zhao 2012). Inorganic arsenic in the soil is inter-converted between the arsenite [As III] and arsenate [As V]. Arsenite predominates in anaerobic environments in contrast to arsenate, which is seen predominantly under aerobic conditions. However, organic monomethylarsonic acid (MMA) and dimethylarsinic acid (DMA) is also present in rice (Meharg and Hartley-Whitaker 2002). Around 50\% of total arsenic in rice is inorganic and the remainder is DMA (Heikens 2006). In South Asian countries the percentage of toxic inorganic arsenic is relatively higher (Rahman and Hasegawa 2011).

Table 1 Arsenic content in Sri Lankan rice ( $\mu \mathrm{g} / \mathrm{dry} \mathrm{Kg}$ )

\begin{tabular}{|c|c|c|c|c|c|c|c|c|c|c|}
\hline & \multicolumn{7}{|c|}{ New improved varieties - area wise } & \multicolumn{3}{|c|}{ Traditional varieties } \\
\hline & Padaviya & Sripura & Maha Wilachchiya & Mihinthale & Kurunegala & Monaragala & Gampaha & $\begin{array}{l}\text { Kalu } \\
\text { Heenati }\end{array}$ & $\begin{array}{l}\text { Mada } \\
\text { Thawalu }\end{array}$ & $\begin{array}{l}\text { Pachcha } \\
\text { Perumal }\end{array}$ \\
\hline & $N=20$ & $N=17$ & $N=25$ & $N=17$ & $N=19$ & $N=11$ & $N=11$ & $N=10$ & $N=10$ & $N=10$ \\
\hline Minimum & 37.2 & 52.4 & 54.2 & 52.4 & 40.2 & 28.8 & 26.6 & 12.8 & 11.6 & 14.4 \\
\hline Maximum & 498.6 & 540.4 & 387.6 & 498.4 & 458.4 & 435.2 & 212.8 & 48.6 & 64.2 & 54.2 \\
\hline Mean & 162.8 & 186.1 & 144.3 & 141.2 & 152.6 & 129.3 & 96.2 & 28.1 & 30.5 & 28.5 \\
\hline Median & 116.8 & 146.2 & 108.4 & 92.5 & 110.6 & 65.4 & 80.6 & 27.6 & 26.7 & 22.4 \\
\hline $\begin{array}{l}\text { Daily As intake } \\
\text { from rice }(\mu \mathrm{g})\end{array}$ & 51.7 & 59.1 & 45.6 & 44.9 & 48.5 & 41.1 & 30.6 & 8.9 & 9.7 & 9.1 \\
\hline
\end{tabular}


Table 2 Trace metal values of traditional varieties of rice-ICP-MS analysis ( $\mu \mathrm{g} / \mathrm{dry} \mathbf{g}$ ) please note that the units are different from Table 1

\begin{tabular}{|c|c|c|c|c|c|c|c|c|c|c|c|c|c|c|c|c|c|c|c|c|c|c|c|}
\hline & $\mathrm{Al}^{1}$ & $\mathrm{Sb}$ & $A s^{1}$ & $\mathrm{Ba}$ & $\mathrm{Be}$ & $C d^{1}$ & $\mathrm{Cr}^{2}$ & Co & $\mathrm{Cu}^{2}$ & $\mathrm{Fe}^{2}$ & $\mathrm{~Pb}^{1}$ & $\mathrm{Mn}^{3}$ & $\mathrm{Hg}^{1}$ & $\mathrm{Mo}^{2}$ & $\mathrm{Ni}^{3}$ & $\mathrm{Se}^{2}$ & $\mathrm{Ag}$ & $\mathrm{Sr}$ & TI & $\mathrm{Sn}^{1}$ & $\mathrm{Ti}$ & $\mathbf{V}^{2}$ & $\mathrm{Zn}^{2}$ \\
\hline Kalu Heenati $(n=6)$ & 4.3 & 0.1 & ND & 0.7 & ND & ND & 0.7 & 0.3 & 2.3 & 7.7 & ND & 9.3 & ND & 0.7 & 1.3 & 0.2 & 0.2 & 0.3 & ND & 0.1 & 0.5 & 1.0 & 11.6 \\
\hline Kuruluthuda $(n=4)$ & 1.5 & 0.1 & ND & 0.6 & ND & ND & 0.7 & 0.3 & 1.8 & 3.1 & ND & 5.2 & ND & 0.4 & 0.6 & 0.2 & ND & 0.2 & ND & 0.1 & 0.3 & 0.9 & 7.15 \\
\hline Madathawalu ( $n=2)$ & 3.3 & 0.1 & ND & 0.6 & ND & ND & 0.7 & 0.3 & 2.4 & 4.8 & ND & 8.0 & ND & 0.4 & 1.4 & 0.2 & ND & 0.2 & ND & 0.1 & 0.3 & 0.9 & 10.9 \\
\hline Kahawanu $(\mathrm{n}=2)$ & ND & 0.1 & ND & 0.3 & ND & ND & 0.7 & 0.3 & 2.2 & 2.1 & ND & 4.0 & ND & 0.6 & 0.8 & 0.2 & ND & 0.1 & ND & 0.1 & 0.2 & 1.0 & 6.45 \\
\hline Kalu Heenati* $(n=2)$ & 2.0 & 0.1 & 0.1 & 1.0 & ND & ND & 0.8 & 0.3 & 2.0 & 12.0 & ND & 16.9 & ND & 0.6 & 2.5 & 0.2 & ND & 0.3 & ND & 0.1 & 0.6 & 1.2 & 17.0 \\
\hline Madathawalu* $(n=2)$ & 2.4 & 0.1 & 0.1 & 3.4 & ND & ND & 0.6 & 0.3 & 1.8 & 7.8 & ND & 17.0 & ND & 0.7 & 1.4 & 0.3 & ND & 0.4 & ND & 0.1 & 0.4 & 1.0 & 17.3 \\
\hline Pachchaperumal* $(n=2)$ & 7.5 & 0.1 & 0.1 & 1.2 & ND & ND & 0.7 & 0.4 & 2.3 & 7.4 & ND & 11.1 & ND & 0.4 & 9.5 & 0.3 & ND & 0.8 & ND & 0.1 & 0.5 & 1.0 & 12.9 \\
\hline
\end{tabular}

${ }^{1}$ Toxic elements ${ }^{2}$ Essential elements and trace elements (in overdose some may be toxic)) ${ }^{3}$ Probably essential elements. (http://apps.who.int/iris/bitstream/10665/ 37931/1/9241561734_eng.pdf).

*non-organically cultivated.

Rice is the staple food of majority of Sri Lankans and is grown widely in the dry zone. In 2010 annual per capita rice consumption in Sri Lanka was $116 \mathrm{Kg}$ (http://www. agridept.gov.lk/images/stories/site/PDF/Publication/English/ BOOK/proposedplan.pdf). In the 1960s the International Rice Research Institute based in Philippines, introduced the new improved varieties (NIV). Development of Bg34-8 at Bathalagoda- a major rice research institute in Sri Lanka with a yield potential of $7 \mathrm{t} /$ ha became very popular, replacing the widely grown traditional variety Pachchaperumal. Within 60 years, NIVs have replaced TVs making them almost extinct. Nevertheless, research has shown that TVs are richer in protein, iron, antioxidants, anti-amylase, anti-glycation and glycation reversing activities in comparison to the NIVs (Gunaratne et al. 2013; Premakumara et al. 2013).

We were unable to perform arsenic speciation due to non-availability of facilities and the lack of funds. However, arsenic speciation is important as it varies with type of rice (Booth 2008). According to the Codex Alimentarius, the maximum allowable limit for inorganic arsenic in rice is $200 \mu \mathrm{g} / \mathrm{kg}$ (http://www.fao.org/news/story/en/item/ $238802 /$ icode/). Assuming that $70 \%$ of the total arsenic content exists in the inorganic form, this corresponds to a level of about $286 \mu \mathrm{g} / \mathrm{kg}$ of total arsenic. As such, $11.6 \%$ of the samples of NIVs exceeded this maximum recommended level in polished rice. Person $(60 \mathrm{~kg}$ of body weight) eating rice obtained from Sripura area consumes approximately $1 \mu \mathrm{g} / \mathrm{kg} /$ day of arsenic. Assuming 70\% of this is inorganic arsenic the daily exposure would approximate to $0.7 \mu \mathrm{g} / \mathrm{kg}$. Although this value exceeds the United States environmental protection agency reference $(0.3 \mu \mathrm{g} / \mathrm{kg} /$ day) (http://www.epa.gov/teach/chem_summ/ Arsenic_summary.pdf) it is below the value recommended by joint FAO/WHO expert committee on food additives (2-7 $\mu \mathrm{g} / \mathrm{kg} /$ day) for the avoidance of potential cancers of skin, lung and bladder (http://www.who.int/ipcs/features/ arsenic.pdf). Highest amount of arsenic $(540.4 \mu \mathrm{g} / \mathrm{kg}$ ) was reported in a sample obtained at Sripura, a farming colony where the CKDu epidemic originated in the 1990s. (Table 1 and Figure 2).

Our measurements reflected the total arsenic content (both inorganic and organic) and the tested NIVs were polished rice but TV were rice with bran. The Codex Alimentarius standard is established for polished rice and not for brown rice. Rice bran was found to contain approximately seven to nine time higher concentrations of total and inorganic arsenic respectively than those found in the corresponding polished rice (Narukawa et al. 2014; Ruangwises et al. 2012). Our results are similar to those of Chandrajith et al. (2011) who reported an arsenic content of $(90-260 \mu \mathrm{g} / \mathrm{kg})$ in an analysis of 10 samples of rice done by ICP-MS in two other endemic areas for CKDu. However, an earlier analysis done by Instrumental Neuron Activation followed by high-resolution $\Upsilon$-ray spectrometry which revealed an arsenic content of 34-92 $\mu \mathrm{g} / \mathrm{kg}$ in rice (Jayasekera and Freitas 2005). There is no difference between the arsenic content in NIVs from the dry zone and wet zone (Gampaha). Compared to NIVs, arsenic content in TVs cultivated without agrochemicals is low, when tested with AAS, (Table 1). These levels are lower than the MDL when tested with ICP-MS method (Table 2). MDL for arsenic in ICP-MS was $25 \mu \mathrm{g} / \mathrm{Kg}$. However, the TVs cultivated using agrochemicals contains $100 \mu \mathrm{g} / \mathrm{Kg}$ of arsenic (Table 2). Furthermore, a higher amount of Fe, $\mathrm{Mn}, \mathrm{Ni}$ and $\mathrm{Zn}$ were also detected in non-organically cultivated TVs than the organically cultivated TVs. Out of the TVs, Madathawalu showed the highest amount of Ba, $\mathrm{Mn}$ and $\mathrm{Zn}$ while Kalu Heenati contained the highest amount of iron. None of the tested TVs contained Be, Cd, $\mathrm{Pb}, \mathrm{Hg}$ and $\mathrm{Tl}$.

These results imply that the arsenic in rice grown in Sri Lanka, originates most probably from the agrochemicals. We have already identified phosphate fertilizers as a main source of arsenic in Sri Lanka (Fernando et al. 2012). Arsenic accumulates in soil following repeated long-term application of contaminated fertilizers. Arsenic in TVs of rice produced without agrochemicals may originate from 
already contaminated soil. Farmers started the cultivation of TVs again without agrochemicals only two seasons prior to our study. Arsenic content in Sri Lankan rice is not as high as in West Bengal, Bangladesh and other East Asian countries (Zhu et al. 2008; Rahman and Hasegawa 2011). However, there is no CKDu similar to Sri Lanka in these countries. Therefore, arsenic in rice cannot be linked directly to the CKDu although the additive effects of arsenic in combination with other heavy metals cannot be ruled out. However, given the high per capita consumption, the adverse effects due to arsenic in rice cannot be overlooked, as it is a non-threshold carcinogen and is linked to many non-communicable diseases (Tchounwou et al. 2003; Kapaj et al. 2006). Jasmine rice from Thailand and Basmati rice (both TVs) from South Asia contain the least amount of arsenic (Potera 2007). The arsenic in the rhizosphere is absorbed through ubiquitous aquaglycoproteins and phosphate channels in the rice roots (Mukhopadhyay et al. 2014). Activity of these proteins and channels and many other factors determines whether rice plant is hyper-tolerant or a hyper-accumulator and whether the rice grain contains excessive amounts of arsenic or not (Srivastava et al. 2012).

Water management and rhizosphere manipulation can alter the arsenic concentration in the rice (Meharg and Zhao 2012). Arsenic content in the rice also can be reduced by rinse washing and cooking it in large amount of water (Raab et al. 2009).

\section{Abbreviations}

CKDu: Chronic kidney disease of unknown origin; NIV: New improved varieties; TV: Traditional varieties; MDL: Method detection limit; MMA: Monomethylarsonicacid; DMA: Dimethylarsinic acid.

\section{Competing interests}

The authors declare that they have no competing interests.

\section{Author's contributions}

CJ, PP, MA and SF designed and performed the experiment; CJ, SS and SG analyzed the data; CJ and SS wrote the first draft of the manuscript. All authors read and approved the final manuscript.

\section{Acknowledgements}

Contribution of Dr. Chinthaka Wijewardhane and Manjula Ranagalage is greatly acknowledged. Project on Higher Education for Twenty first Century (HETC) of the University Grants Commission and Farmers trust fund of Sri Lanka provided the financial support. IIRMES lab director Richard Gossett and his staff extended their maximum support for the analytical study. We are extremely grateful for the expert comments by two anonymous reviewers that helped to enhance the quality of the manuscript.

\section{Author details}

${ }^{1}$ Faculty of Medicine\& Allied Sciences, Rajarata University of Sri Lanka, Saliyapura 50008, Sri Lanka. ${ }^{2}$ Faculty of Science, University of Kelaniya, Colombo 11600, Sri Lanka. ${ }^{3}$ Department of Health Science, California State University Long Beach, Long Beach, CA 90840, USA. ${ }^{4}$ Faculty of Medicine \& Allied Sciences, Rajarata University of Sri Lanka, Saliyapura 50008, Sri Lanka.

Received: 24 November 2014 Accepted: 7 January 2015

Published online: 30 January 2015

\section{References}

Booth B (2008) Arsenic speciation varies with type of rice. Environ Sci Technol 42:3484-3485

Chandrajith R, Nanayakkara S, Itai K et al (2011) Chronic kidney diseases of uncertain etiology (CKDue) in Sri Lanka: geographic distribution and environmental implications. Environ Geochem Health 33:267-78

Europian Food Safety Authority (2009) Scientific Opinion on Arsenic in Food 1. EFSA J 7:1351

Fernando A, Jayalath K, Fonseka SI, Jayasumana MACS, Amarasinghe MD, Senanayake VK, Kannangara A, et al. (2012) Determination of Arsenic content in synthetic and organic manure based fertilizers available in Sri Lanka. In Proceedings of the International Conference on Chemical Sciences, Institute of Chemistry, Ceylon Colombo, Sri Lanka, 129-134

Gunaratne A, Wu K, Li D et al (2013) Antioxidant activity and nutritional quality of traditional red-grained rice varieties containing proanthocyanidins. Food Chem 138:1153-1161

Heikens A (2006) Arsenic contamination of irrigation water, soil and crops in Bangladesh: risk implications for sustainable agriculture and food safety in Asia. 1st edition, RAP publishers, Bangkok, Thailand, pp19-21

Jayasekera RJ, Freitas MC (2005) Concentration Levels of Major and Trace Elements in Rice from Sri Lanka as Determined by the k 0 Standardization Method. Biol Trace Elem Res 103:83-96

Jayasumana C, Gunatilake S, Senanayake P (2014) Glyphosate, hard water and nephrotoxic metals: Are they the culprits behind the epidemic of chronic kidney disease of unknown etiology in Sri Lanka? Int J Environ Res Public Health 11:2125-2147

Jayasumana MACS, Paranagama PA, Amarasinghe MD et al (2013) Possible link of Chronic arsenic toxicity with Chronic Kidney Disease of unknown etiology in Sri Lanka. J Nat Sci Res 3:64-73

Jayatilake N, Mendis S, Maheepala P, Mehta FR (2013) Chronic kidney disease of uncertain aetiology: prevalence and causative factors in a developing country. BMC Nephrol 14:180

Kapaj S, Peterson H, Liber K, Bhattacharya P (2006) Human health effects from chronic arsenic poisoning-a review. J Environ Sci Health A Tox Hazard Subst Environ Eng 41:2399-2428

Meharg AA (2004) Arsenic in rice-understanding a new disaster for South-East Asia. Trends Plant Sci 9:415-417

Meharg AA, Hartley-Whitaker J (2002) Arsenic uptake and metabolism in arsenic resistant and nonresistant plant species. New Phytol 154:29-43

Meharg AA, Zhao FJ (2012) Arsenic and Rice. Springer Science \& Business Media, London

Mukhopadhyay R, Bhattacharjee H, Rosen BP (2014) Aquaglyceroporins: generalized metalloid channels. Biochim Biophys Acta 1840:1583-91

Narukawa T, Matsumoto E, Nishimura T, Hioki A (2014) Determination of Sixteen Elements and Arsenic Species in Brown, Polished and Milled Rice. Anal Sci $30: 245-250$

Potera C (2007) Food Safety: U.S. Rice Serves Up Arsenic. Environ Health Perspect 115:A296

Premakumara GAS, Abeysekera WKSM, Ratnasooriya WD et al (2013) Antioxidant, anti-amylase and anti-glycation potential of brans of some Sri Lankan traditional and improved rice (Oryza sativa L.) varieties. J Cereal Sci 58:451-456

Raab A, Baskaran C, Feldmann J et al (2009) Cooking rice in a high water to rice ratio reduces inorganic arsenic content. J Env Monit 11(1):41-44

Rahman MA, Hasegawa H (2011) High levels of inorganic arsenic in rice in areas where arsenic-contaminated water is used for irrigation and cooking. Sci Total Environ 409:4645-4655

Ruangwises S, Saipan P, Tengjaroenkul B et al (2012) Total and Inorganic Arsenic in Rice and Rice Bran Purchased in Thailand. J Food Protection 75(4):771-774

Srivastava S, Suprasanna P, D'Souza SF (2012) Mechanisms of arsenic tolerance and detoxification in plants and their application in transgenic technology: a critical appraisal. Int J Phytoremediation 14:506-17

Tchounwou P, Patlolla A, Centeno J (2003) Carcinogenic and Systemic Health Effects Associated with Arsenic Exposure - A Critical Review. Toxicol Pathol 31:575-588

Tsuji JS, Yost LJ, Barraj LM et al (2007) Use of background inorganic arsenic exposures to provide perspective on risk assessment results. Regul Toxicol Pharmacol 48:59-68

Yost LJ, Schoof RA, Aucoin R (1998) Intake of Inorganic Arsenic in the North American Diet. Hum Ecol Risk Assess An Int J 4:137-152

Zhu YG, Williams PN, Meharg AA (2008) Exposure to inorganic arsenic from rice: A global health issue? Environ Pollut 154:169-171 